International Journal of Instruction e-ISSN: 1308-1470 • www.e-iji.net

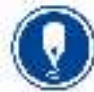

April 2021 • Vol.14, No.2

p-ISSN: 1694-609X

pp. $903-918$

Article submission code

20200505021407

Received: 05/05/2020

Revision: 02/11/2020

Accepted: 24/11/2020

OnlineFirst: 12/03/2021

\title{
Developing Creative Entrepreneurship through Experience-based Learning: Creating products of Guangxi, China to Thailand
}

\section{Zhou Xiumiao}

School of Foreign Language, Baise University, China, 1433260863@qq.com

\section{Mayuree Suacamram}

School of Foreign Language, Baise University, China \& Graduate School, Western University, Thailand,2393438425@qq.com

Experience-based learning (EBL) is an allowing learners to develop through learning experience. Creative entrepreneurship (CE) requires learners to gain real hand-on experience. This study aimed to develop CE through EBL and examine the results. The sample group consisted of 30 fourth-year Chinese students majoring in Thai language. $\mathrm{CE}$ and creative performance (CP) were assessed by a test and a rubric evaluation. Data analysis was conducted using dependent $t$-test and repeated measurement. The findings showed that the lesson plans began with the teacher giving examples of business in Thailand and explaining principles of $\sigma \mathrm{W} 1 \mathrm{H}, \mathrm{PEST}$ and STP. Next, the students developed product ideas from Guangxi, China to market in Thailand. They conducted interviews with the entrepreneurs to create a strategic plan based on the CANVAS Model. After the lesson implementation, the result revealed that their CE and CP had increased.

Keywords: creative entrepreneurship, experience-based learning, new products, Guangxi products, Thailand

\section{INTRODUCTION}

Creative entrepreneurship (CE) is important for Chinese students. Especially Teaching entrepreneurship to Chinese students has obstacles to access to communication platforms such as Facebook (Parry \& Baird, 2012). Instructors need to speed up the development of creative entrepreneurship. This is because economy has been moving from knowledge-based activities to creativity, innovation, entrepreneurship and imagination-based activities (van den Broeck et al., 2008; Oke et al., 2009). CE is often used in creative industries. It means setting up and manage a business risk in one the creative industries (Bujor \& Avasilcai, 2014; De Pinho, 2011; UNCTAD, 2008) Creative entrepreneurs must also be innovators, who apply a new process, solution, or product to their business. They also have creative strategies to motivate their employees. (Bujor \& Avasilcai, 2014; Darling et al., 2007; de Jong \& Den Hartog, 2007) However, CE should not only be emphasized in the creative industries but it should also be a focus

Citation: Xiumiao, Z., \& Suacamram, M. (2021). Developing Creative Entrepreneurship through Experience-based Learning: Creating products of Guangxi, China to Thailand. International Journal of Instruction, 14(2), 903-918. https://doi.org/10.29333/iji.2021.14251a 
of developing Chinese students by using different development methods according to learners' characteristics. Yu (2015) conducted a research study regarding developing CE programs of Chinese students and found that Chinese designers' entrepreneurial intentions were positive. Bridgstock \& Carr (2013) studied about developing enterprise capabilities for creative arts students. The study showed that creative arts-specific enterprise curriculum can develop student enterprise behaviors such as: grant seeking, professional networking and intention to start an enterprise. Entrepreneurial experience also positively affects opportunity discovery and opportunity exploitation (Rerup, 2005). In summary, CE is a soft skill that Chinese students should be able to develop through experiential learning.

Experience-based Learning (EBL) is a process of picking up knowledge and skills from real experience. To develop entrepreneurship, one must take part in the process of developing entrepreneurship through their experience, so he or she must be able to explain his/her own learning or create their knowledge from his/her own experiences (Williams et al., 2014). The Association to Advance Collegiate Schools of Business (AACSB) recognized in the 2002 reported that experiential education kept students connected to rapidly changing business models. EBL encourages constructive interactions during the learning process in the classroom and business world enabling learners to connect changes of business models (Good, Boyas \& Klein, 2019). Entrepreneurial thinking is very helpful for them in all aspects of their personal life and in a broad variety of their future jobs and capacities (Yuste, et al, 2014). Therefore, CE development by using EBL also is necessary for their jobs.

Baise University, China plays an important role in preparing their students before they enter their career. One of the courses taught in Thai language is called---"Case studies of business in Thailand". This course focuses on having the students experience new product development. It is consistent Lyons \& Zhang (2018) research, found that those who participate in activities entrepreneurs' programs become more entrepreneurial. This increase is different between those with different business experience. In other words, past experience and participation in entrepreneurship development programs have an impact on entrepreneurship. In addition, Baum and Bird (2010) revealed that knowledge and intelligence developed from experience have positive influence toward business growth especially during the start of the business. Therefore, creative entrepreneurship development is very crucial.

To sum up, we are interested in developing student's creative entrepreneurship through experience-based learning (Good, Boyas \& Klein, 2019). In the Case Studies of Business in Thailand course, the instructor acted as coach to give guidance to the students and create a learning environment focusing on how to create a new product of Guangxi, China for selling in Bangkok, Thailand. To be successful, the instructors contact experts and business owners to provide advice and encouragement for learners to create new products. This research describes the students' learning process and their creative entrepreneurship. The finding be beneficial for instructors who would like to create a learning process to develop their students' creative entrepreneurship. 
Curriculum administrators can also make use of the findings for planning and making decisions about the course structure.

\section{RESEARCH OBJECTIVE}

1. To develop creative entrepreneurship through EBL by Creating products of Guangxi, China to Thailand.

2. To examine the results of developing creative entrepreneurship and creative performance.

\section{LITERATURE REVIEW}

\section{Creative Entrepreneurship: definitions and components of measurement}

In the past, creativity and entrepreneurship were categorized in a different construct (Stein, 1974). Creativity is the ability to produce work that is both new and valuable (Pratt, 2008). Creativity could be imagination or performance of a person (VandenBos, 2007 ; Torrance, 2008). It was a result of integrating knowledge and experiences to form ideas or hypotheses and then the hypotheses are tested to verify a new finding (Torrance, 2008; Livingston, 2010). While entrepreneurship seeks to perceive opportunities and brings them to reality, in order to capture a part of the value created (Hartley et al., 2012). Entrepreneurship has three dimensions: innovation, risk-taking and proactiveness. Entrepreneur's characteristics include competitive advantage, strategic weapon, embedded philosophy, contributing to employer and employee motivation, problem solving and improved performance (Fillis \& Rentschler, 2010). An entrepreneur who has creativity, he/she will create a new and valuable product to the market. This is called 'creative entrepreneurship'.

Currently, creativity is integrated in entrepreneurship. Entrepreneurs are seen as innovators who bring something new to their business process or organizational capability. Joseph Schumpeter said 'without innovations, no entrepreneurs' (Bujor \& Avasilcai, 2014; Zwick, 2008). They also select a partner to complete their business, classify creative solutions, and manage conflicts between creative one and the business management. The creative one seek uniqueness or originality while the business management will seek efficiency (Bujor \& Avasilcai, 2014). In addition, the entrepreneurs are leaders who use creative strategies to motivate their employees (Darling et al., 2007; de Jong and Den Hartog, 2007).

United Nations Conference on Trade and Development (UNCTAD, 2008) states creative entrepreneurship means developing or operating ventures in creative industries. The creative industries are divided into 3 sectors: arts, media and entertainment and creative business service. Creative entrepreneurship combines creation, production, and commercialization of creative elements. (Bujor, \& Avasilcai, 2014 ; De Pinho, 2011). It is also the practice of establishing a business by yourself in one of the creative industries. The creative entrepreneurs will focus first and foremost with the creation and exploitation of creative or intellectual capital. (Bujor \& Avasilcai, 2016 ; Caves, 2000) They can create values in the incubation process through its entry and exit procedure and by providing start-ups with facilities, knowledge and networks. (De Pinho, 2011). 
There are 5 main characteristics of creative entrepreneurs: self-confidence, perseverance, high energy levels, calculated risk taking and the need to achieve (Fillis \& Rentschler, 2010). Creative artists and entrepreneurs have the same characteristics and sociodemographic profiles: "outsiders". Most of the time, they are very independent. They have medium intelligence and imagination, high ambiguity tolerance, risk-loving, unusual degree of persistence. (Bujor, \& Avasilcai, 2014).

\section{Definitions and elements of the experience-based learning}

The experience-based learning (EBL) adopts the constructivist theory. This theory focuses on two aspects: 1. Being constructive is a trait of activities that learners gain knowledge from their experience and 2. Alignment means how to match the right learning activities with proper learning objectives (Caniglia et al., 2016). EBL refers to a development of knowledge and skills through prior experience or current experience (Kurka, 2012 ; Mollaei \& Rahnama, 2012 ; Tsai et al., 2018). Learners analyze and interpret their own experience by a process of reflecting, evaluating and reconstructing to gain knowledge from their own experience (Kurka, 2012; Lundgren et al., 2017 ; Tsai et al., 2018). Kolb's Experiential Learning Theory Model features two dimensions. First, it focuses on grasping experience through concrete experience and abstract conceptualization. Second, transforming experience looks at reflective observation and active experimentation. He also suggested that the model is characterized by three key elements (Kolb, 1984):

1) Involvement: Learners are involved in learning activities exploiting their intelligence, emotions and feelings during their learning.

2) Recognition: Learners recognize activities that are related to life and learning experience.

3) Continued reflection: Learners reflect upon their learning continuously and reveal what they have learned from their experience.

\section{Process of EBL}

EBL involves 4 basic processes for transforming experience to learning: (a) concrete experience, (b) reflective observation, (c) abstract conceptualization, and (d) active experimentation (Kolb, 1984). All of the 4 processes are learning via experience process. Critical thinking is the most vital for learners to reflect upon their experience. Reflection refers to mechanism for constructing knowledge from experience. Teachers should ensure that learners are encouraged to have self-reflection and group reflection about what they have learned (Blackburn, Robinson \& Kacal, 2015). Evidently, all experiences are founded upon earlier events in the life of the learners, current life events, or those arising from the learner's participation in the activities designed and implemented by teachers acting as facilitators (Namaziandost, Nasri \& Esfahani, 2019). 


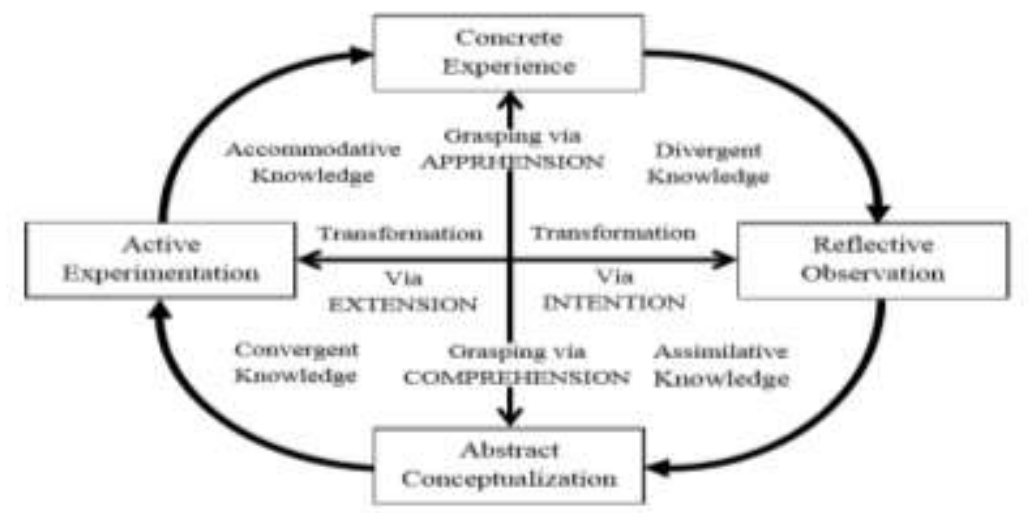

Figure 1

Process of Experience-based learning

Source: Kolb (1984)

\section{EBL and Entrepreneurship learning process}

To learn entrepreneurship, learners are involved in the entrepreneurship learning process to gain experiential knowledge or 'learning by doing' (Pittaway and Cope 2007 ; Read et al., 2011; Sarasvathy, 2008). As the EBL, the learners are required to criticize, reflect and interpret during the entrepreneurial experience. The role of the educator in this learning process is being a mentor. The educator should provide the conditions for experience-based learning, both entrepreneurial experience and reflection. What is important is to have learners participate in outside classroom activities. They gain up-todate knowledge and real experience. Moreover, it is an opportunity for learners to establish a network for their development as an entrepreneur in the future (Williams et al., 2014). The instructor writes the lesson plan in accordance with the Process of Experience-based learning by providing the student with an entrepreneurial experience. After that, the learners give the feedback their own learning. The teacher is the listener and guides the learners to have the highest learning experience.

\section{Related studies}

Both research studies conducted in companies and classrooms found that a person can develop creativity and entrepreneurship or creative entrepreneurship from experiencebased learning. The research in a company collecting data from 74 creative managers revealed that the keys to acquire entrepreneurial competence were education and experience, communication and networking (Küttim, Arvola \& Venesaar, 2011). Five research studies in classrooms showed that students through experiential learning developed both theoretical education and demonstrated behavioural change. The instructor assigns the exercises and the learners will concrete their understanding of real experience. After that, the students reflect on the thinking and the instructor gives suggestions for behaviour development (Otte, 2016). A research found that students were able to increase both creativity and entrepreneurship in an academic environment. 
They had a combination of learning workshops using Skype, involving a book author, and a multilingual multicultural class between 2 countries. Both Korean and Indonesian learners can remove the walls and text books from the classroom. Students gain new experiences from foreign friends. The instructor also uses discussions to enable students to reflect and create the correct knowledge and understanding. (Parry \& Baird, 2012). The EBL process from Otte (2016) and Parry \& Baird (2012) is similar to the concept of Kolb (1984) in Figure 1.

From the foregoing, research has also shown that Experience-based learning can develop both enterprise competency and other soft skill. After having this type of learning experience, students showed their want to become an entrepreneur (Bridgstock \& Carr, 2013; Parry \& Baird, 2012; Yu, 2015) and increasingly portrayed enterprise behaviors such as grant seeking, professional networking, and employability (Bridgstock \& Carr, 2013). For other soft skill development, students can develop collaborative, systematic thinking, and critical writing skills through doing exercises on field surveys and/or exchanging ideas. After that, instructor ask them to give feedback on the presentations (Caniglia et al., 2016 ; Parry \& Baird, 2012).

\section{METHOD}

This research is a development research divided into 2 steps according to the research objectives as follows: 1) To study methods of creative entrepreneurship development by creating a teaching plan. 2) To Study the results of creative entrepreneurship development of Student.

\section{Population and Sample}

The population was a total of 110 fourth-year Chinese students majoring in Thai language and studying in Thailand for 1 year. There are 12 sections registered in the Case Studies of Business in Thailand course. Each classroom is assorted according to the student's GPA. The samples obtained by cluster random sampling was a class of 30 students who were taking with me. Among the 30 students, there were 28 females and 2 males.

\section{Measurement}

Creative Entrepreneurship (CE) means ability to manage business with new methods to develop products such as new innovations. $\mathrm{CE}$ is made on consideration of corresponding components of characteristics of creative entrepreneurs (Bujor, \& Avasilcai, 2014; Fillis \& Rentschler, 2010), Dimension of Entrepreneurship (Fillis \& Rentschler, 2010), and Dimension of Creativity (Reisman, Keiser, \& Otti, 2016). There are 24 items in 3 components: 1) Perseverance for achievement means the effort of an intrinsic motivation to succeed something, even if there are obstacles or things that have never been done 2) Risk taking means braveness or an open mind to accept the risk that has been assessed by studying the information carefully and 3) Innovation and new idea means the ability to think of new things in many more different ways than others. Each component use the questions based on the Reisman, Keiser, \& Otti (2016) which has 7, 8 , and 9 items, respectively. Each item has 6 levels which are strongly agree, agree, 
more or less agree, more or less disagree, disagree, and strongly disagree. Cronbach's alpha in each component was $0.820,0.722$, and 0.891 respectively.

Creative Performance (CP) refers to students' idea expression for product development of each group. Their ideas were completely expressed based on the principles of product analysis: W1H, PEST, STP, SWOT, Marketing Mix 7P, and Canvas model. Students in each group were required to come up with a new product and present it to the experts and get feedback for developing their products. CP was measured by a rubric evaluation under two criteria: complete content and creativity. Content validity of the rubric evaluation was ensured by 3 experts who were instructors and business experts in China or Thailand. The score of the Index of Item-Objective Congruence (IOC) was between $0.667-1.000$

\section{Data analysis}

The lesson plans, a result of creative entrepreneurship, and new ideas of students were analyzed using content analysis. A comparison of creative entrepreneurship development between pre-posttest using dependent t-test was made. A comparison of performance development as seen in 3 presentations was drawn based on repeated measurement ANOVA.

\section{FINDINGS}

In response to the two research objectives, the findings were reported under two topics as follows:

\section{The lesson plans for developing creative entrepreneurship based on EBL}

According to EBL process, lesson plans were divided into 2 rounds that based on concrete experience, reflective observation, abstract conceptualization, and active experimentation. The lesson plans indicated clear learning outcomes that learners learn and have experience about creating new products of Guangxi, China for marketing in Thailand. The lesson plan for every student in each week is showed in Table 1. 
Table 1

Lesson plans based on EBL to develop creative entrepreneurship of Chinese students

\begin{tabular}{|c|c|c|c|c|c|}
\hline Week & Objectives & Content & Instructor's role & Students' role & Asses. \\
\hline \multicolumn{6}{|l|}{ Round1 } \\
\hline 1,3 & $\begin{array}{l}\text { To understand } \\
\text { business situations in } \\
\text { Thailand, 6W1H, } \\
\text { PEST, and STP } \\
\text { concept }\end{array}$ & $\begin{array}{l}\text { - situations and } \\
\text { case studies of } \\
\text { business in } \\
\text { Thailand } \\
\text { - 6W1H, PEST, } \\
\text { STP }\end{array}$ & $\begin{array}{l}\text { - Explain the concept } \\
\text { of } 6 \mathrm{~W} 1 \mathrm{H}, \mathrm{PEST}, \mathrm{STP} \\
\text { - encourage reviewing } \\
\text { situations of business } \\
\text { in Guangxi, China and } \\
\text { Thailand }\end{array}$ & $\begin{array}{l}\text { Review experience } \\
\text { about Guangxi and } \\
\text { Thailand's business } \\
\text { situations }\end{array}$ & $A^{* * 1}$ \\
\hline 2,4 & $\begin{array}{l}\text { To create new idea by } \\
\text { using } 6 \mathrm{~W} 1 \mathrm{H}, \mathrm{PEST} \text {, } \\
\text { STP and their } \\
\text { experience }\end{array}$ & $\begin{array}{l}\text { - how to create } \\
\text { new ideas }\end{array}$ & $\begin{array}{l}\text { - encourage and coach } \\
\text { new ideas. }\end{array}$ & $\begin{array}{l}\text { Observe their } \\
\text { experience and create } \\
\text { new ideas about } \\
\text { Guangxi products }\end{array}$ & $\mathrm{A}^{* *}$ \\
\hline 5 & $\begin{array}{l}\text { To conceptualize a } \\
\text { new product from } \\
\text { Guangxi to market in } \\
\text { Thailand }\end{array}$ & $\begin{array}{l}\text { New products } \\
\text { from Guangxi to } \\
\text { market in Thailand }\end{array}$ & - comment and advise & $\begin{array}{l}\text { - present new products } \\
\text { from Guangxi to market } \\
\text { in Thailand by using } \\
\text { 6W1H, PEST, STP }\end{array}$ & $\mathrm{B}^{* * 2}$ \\
\hline 6,7 & $\begin{array}{l}\text { To recheck and } \\
\text { develop student's } \\
\text { ideas with } 12 \\
\text { enterprises }\end{array}$ & $\begin{array}{l}\text { Thinking about } \\
\text { questions and } \\
\text { interview } \\
\text { techniques }\end{array}$ & $\begin{array}{l}\text { - give guidance on } \\
\text { about creating } \\
\text { questions } \\
\text { - explain and } \\
\text { demonstrate interview } \\
\text { techniques } \\
\text { - monitor during the } \\
\text { interview with the } \\
\text { enterprises }\end{array}$ & $\begin{array}{l}\text { - think about questions } \\
\text { and interview } 12 \\
\text { enterprises in Guangxi }\end{array}$ & $\mathrm{A}^{* *}$ \\
\hline \multicolumn{6}{|l|}{ Round2 } \\
\hline 8,10 & $\begin{array}{l}\text { To understand } \\
\text { SWOT, strategic } \\
\text { planning, Marketing } \\
\text { Mix, and Canvas } \\
\text { concept }\end{array}$ & $\begin{array}{l}\text { SWOT, Strategic } \\
\text { plan, Marketing } \\
\text { Mix, Business } \\
\text { Model Canvas }\end{array}$ & $\begin{array}{l}\text { - Explain concept of } \\
\text { SWOT, Strategic plan, } \\
\text { Marketing Mix, } \\
\text { Business Model } \\
\text { Canvas } \\
\text { - encourage reviewing } \\
\text { student's experience } \\
\text { from interview with the } \\
\text { enterprises }\end{array}$ & $\begin{array}{l}\text { Review experience } \\
\text { gained from the } \\
\text { interview }\end{array}$ & $A^{* *}$ \\
\hline 9,11 & $\begin{array}{l}\text { To create a business } \\
\text { strategic plan } \\
\text { by using SWOT, } \\
\text { Marketing Mix, } \\
\text { Business Model } \\
\text { Canvas, and findings } \\
\text { from enterprise } \\
\text { interview }\end{array}$ & $\begin{array}{l}\text { - how to create a } \\
\text { business strategic } \\
\text { plan }\end{array}$ & $\begin{array}{l}\text { - encourage and coach } \\
\text { strategic thinking }\end{array}$ & $\begin{array}{l}\text { - observe their } \\
\text { experience from the } \\
\text { interview } \\
\text { - create a strategic plan } \\
\text { for Guangxi products }\end{array}$ & $\mathrm{A}^{* *}$ \\
\hline 12,13 & $\begin{array}{l}\text { To conceptualize a } \\
\text { business strategic } \\
\text { plan of developing } \\
\text { Guangxi product to } \\
\text { market in Thailand }\end{array}$ & $\begin{array}{l}\text { Business } \\
\text { strategies to } \\
\text { develop Guangxi } \\
\text { products to market } \\
\text { in Thailand } \\
\end{array}$ & - comment and advise & $\begin{array}{l}\text { - present their business } \\
\text { strategic plans }\end{array}$ & $\mathrm{B}^{* * *}$ \\
\hline 14,15 & $\begin{array}{l}\text { To recheck and } \\
\text { develop student's } \\
\text { strategic plan with } \\
\text { experts }\end{array}$ & $\begin{array}{l}\text { International } \\
\text { business } \\
\text { techniques }\end{array}$ & $\begin{array}{l}\text { - facilitate and } \\
\text { moderate during expert } \\
\text { coaching by face to } \\
\text { face and video call } \\
\text { online }\end{array}$ & $\begin{array}{l}\text { - present Guangxi } \\
\text { products to market in } \\
\text { Thailand }\end{array}$ & $\mathrm{C}^{* * 1}$ \\
\hline
\end{tabular}

Remark: *A=Observe by instructor, $\mathrm{B}=$ Rubric evaluation by instructor, $\mathrm{C}=$ Rubric evaluation by experts $* *$ Asses. $=$ Assessment

International Journal of Instruction, April $2021 \bullet$ Vol.14, No.2 
Learning outcomes from the first two weeks showed that the students had created 8 new products for business in Thailand: 1) a tea shop 2) a flower tea shop 3) a Lausue noodle restaurant 4) hot pot instant noodle 5) Traditional Chinese costume rental shop 6) Chinese language training school 7) Chinese Trinkets and 8) supplement made from Chinese dates. Throughout 15 weeks, students underwent learning process via experience in developing products which increased their development of creative entrepreneurship and creative performance as in the following detail.

\section{The results of developing creative entrepreneurship and creative performance}

A comparison of the students' creative entrepreneurship before and after the lesson implementation illustrated that all of the 30 students showed statistically significant increase in developing creative entrepreneurship $(\mathrm{t}=-3.359 \mathrm{P}=0.002)$ with $6.413 \%$ increase of the mean score. When compared the creative entrepreneurship in each aspect, it was found out that only the mean scores for perseverance for achievement and innovation and new ideas were increased and the increase was statistically significant ( $\mathrm{t}$ $=-4.140$ and $-2.654, \mathrm{P}=0.000$ and 0.013 respectively). They were $9.091 \%$ and $7.276 \%$ increase respectively. In terms of risk taking, the mean score was increased but the increase was not statistically significant $(\mathrm{P}>0.05)$.

Table 2

A comparison of creative entrepreneurship between pre-posttest

\begin{tabular}{|c|c|c|c|c|c|}
\hline & Measurement & Mean & Std. & $\mathrm{t}$ & P-value \\
\hline \multirow{2}{*}{$\begin{array}{l}\text { Creative } \\
\text { entrepreneurship }\end{array}$} & Pretest & 4.210 & 0.374 & \multirow[t]{2}{*}{-3.359} & \multirow[t]{2}{*}{0.002} \\
\hline & Posttest & 4.480 & 0.444 & & \\
\hline \multirow{2}{*}{$\begin{array}{l}\text { 1) Perseverance } \\
\text { for achievement }\end{array}$} & Pretest & 4.224 & 0.451 & \multirow[t]{2}{*}{-4.140} & \multirow[t]{2}{*}{0.000} \\
\hline & Posttest & 4.608 & 0.508 & & \\
\hline \multirow[t]{2}{*}{ 2) Risk taking } & Pretest & 4.354 & 0.397 & \multirow[t]{2}{*}{-1.449} & \multirow[t]{2}{*}{0.158} \\
\hline & Posttest & 4.495 & 0.468 & & \\
\hline \multirow{2}{*}{$\begin{array}{l}\text { 3) Innovation } \\
\text { and new idea }\end{array}$} & Pretest & 4.068 & 0.534 & \multirow[t]{2}{*}{-2.654} & \multirow[t]{2}{*}{0.013} \\
\hline & Posttest & 4.364 & 0.527 & & \\
\hline
\end{tabular}

According to the comparison of eight groups' creative performance showed in three sessions of presentations, the mean scores of all of the eight groups showed statistically significant increase in development of creativity (Wilks' Lambda $=4.059 \mathrm{P}=0.047$, Mauchly's Test of Sphericity $=8.290 \mathrm{P}=0.016)$. Even though the mean score of the second presentations slightly decreased (equal to $2.879 \%$ ), the mean score of the third presentations significantly increased (equal to $17.647 \%$ ). In terms of the completeness of the content, the result showed that the mean scores of all of the eight groups increased but the increase was not statistical significant (Wilks' Lambda $=0.974 \mathrm{P}=0.924$, Mauchly's Test of Sphericity $=0.798 \mathrm{P}=0.509$ ) as seen in Table 4 or it can be said that students in 8 groups didn't show development in this area when compared to their first presentations. Therefore, it can be said that the EBL can develop student presentations only in the creative but cannot develop the content. 
Table 3

Comparison of Creative Performance from three sessions of the presentations

\begin{tabular}{lllllll}
\hline & Creativity1 & Creativity2 & Creativity3 & Content1 & Content2 & Content3 \\
\hline Mean & 2.188 & 2.125 & 2.500 & 2.500 & 2.563 & 2.538 \\
\hline S.D. & 0.259 & 0.231 & 0.378 & 0.378 & 0.438 & 0.213 \\
\hline
\end{tabular}

However, when creativity performance of each group was compared, there were four groups that showed increase in developing creative products. They were: 1) Chinese noodle shop, 2) flower tea, 3) Chinese dress rental shop, and 4) Chinese red dates (Figure 2). Product development of these four groups illustrated unique ideas and their ideas were more and more detailed and elaborated in each presentation sessions. The features of their products presented in their third product presentations were totally different from their first presentations. The products they presented were more unique and distinctive from typical products found in the market (Table 4). Therefore, it can be said that the development of creativity comes from the development of ideas that are completely different.

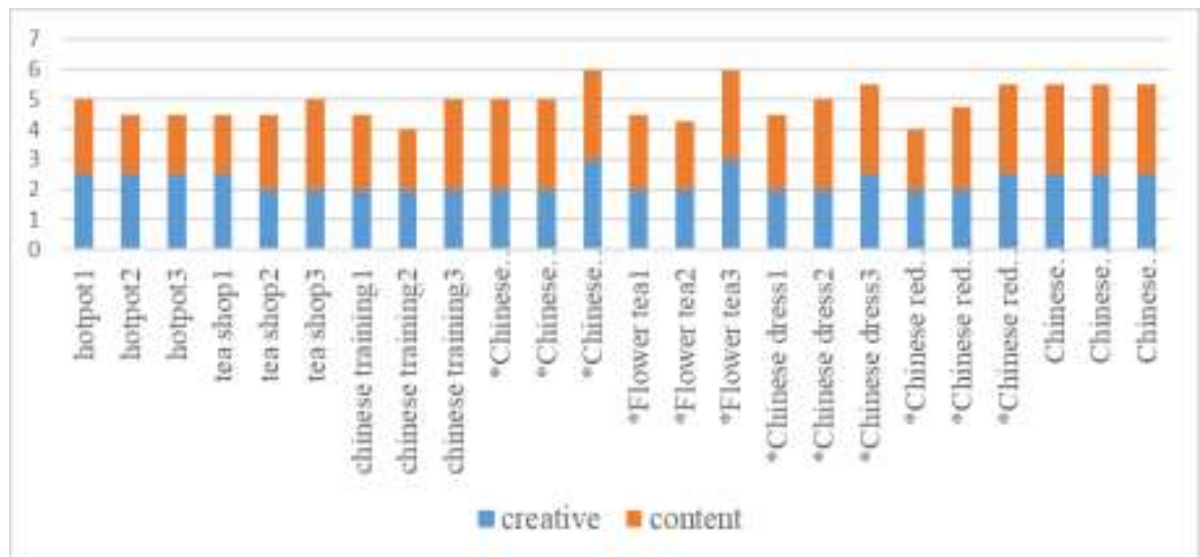

Note: *groups that showed increase in developing creative products

Figure 2

creativity and complete content of the 8 groups' presentations in their three presentation sessions 
Table 4

Examples of product development of the groups that showed increase in creativity score.

\begin{tabular}{|c|c|c|c|}
\hline \multirow[t]{2}{*}{ Group } & \multicolumn{3}{|c|}{ Product presentations } \\
\hline & Session 1 & Session 2 & Session 3 \\
\hline $\begin{array}{l}\text { 1) Chinese } \\
\text { Noodle }\end{array}$ & $\begin{array}{l}\text { Delicious flavor/ } \\
\text { cheap price }\end{array}$ & $\begin{array}{l}\text { Rich flavor: } \\
\text { Spicy, sour and salty }\end{array}$ & $\begin{array}{l}\text { Focus on flavor and quality of } \\
\text { the handmade noodle }\end{array}$ \\
\hline $\begin{array}{l}\text { 2) Flower } \\
\text { tea }\end{array}$ & $\begin{array}{l}\text { Flower tea from } \\
\text { Yunnan province }\end{array}$ & $\begin{array}{l}\text { Various types of flower } \\
\text { tea have different } \\
\text { benefits }\end{array}$ & $\begin{array}{l}\text { Flower tea in a fancy package } \\
\text { and a demonstration of } \\
\text { authentic traditional Chinese } \\
\text { tea making }\end{array}$ \\
\hline $\begin{array}{l}\text { 3) Chinese } \\
\text { dress } \\
\text { rental } \\
\text { shop }\end{array}$ & $\begin{array}{l}\text { Various traditional } \\
\text { Chinese costumes }\end{array}$ & $\begin{array}{l}\text { Authentic traditional } \\
\text { Chinese costumes and } \\
\text { accessories }\end{array}$ & $\begin{array}{l}\text { accentuating costumes creating } \\
\text { an elegant feeling } \\
\text { Real Chinese dressing style and } \\
\text { make up. }\end{array}$ \\
\hline $\begin{array}{l}\text { 4) Chinese } \\
\text { red dates }\end{array}$ & $\begin{array}{l}\text { Sweet Chinese } \\
\text { dates }\end{array}$ & $\begin{array}{l}\text { Chinese red dates, } \\
\text { Chinese red date tea and } \\
\text { sweets made from } \\
\text { Chinese red dates }\end{array}$ & $\begin{array}{l}\text { Making Chinese red date teas } \\
\text { sweeter } \\
\text { Sweets shaped in cartoons, } \\
\text { easily accessible to customers. }\end{array}$ \\
\hline
\end{tabular}

\section{DISCUSSION AND SUGESTIONS}

According to the findings, only perseverance for achievement and innovation and new idea were developed. As for risk taking, students didn't demonstrate much improvement. This was because students didn't have much opportunity to run a real business involving real risk with their products. Therefore, their awareness about risk taking remained the same. The result of their self-assessment showed the same level. The detail about the development of perseverance for achievement and innovation and new ideas are described below:

\section{Perseverance for achievement}

All of the four leaning processes based on EBL: (a) concrete experience, (b) reflective observation, (c) abstract conceptualization, and (d) active experimentation (Kolb, 1984) enable learners to gain knowledge from their experience. In this study, the teacher organized activities for learners to learn according to the abovementioned processes as shown in Table 2. The learners reflected on the knowledge and experience they have gained and then conceptualized their own ideas and seek advice from the real entrepreneurs and experts. After that, they summarized their knowledge concepts by themselves. This learning process allows the students to think and act on their own encouraging them to have determination and strive for achievement by themselves. As a result, perseverance for achievement is increased. It is consistent with one of the characteristics of entrepreneurs as indicated by Fillis \& Rentschler (2010) which include self-confidence, perseverance, high energy levels, and the need to achieve.

\section{Innovation and new ideas}

EBL allows learners to gain extensive knowledge and experience for generating new ideas by themselves and by sharing ideas with others. The same goes with entrepreneurs 
who need to foster creativity since the beginning of designing a product, production process and employing strategies to connect knowledge, interpersonal thinking (Darling et al., 2007; de Jong and Den Hartog, 2007 ; De Pinho, 2011). Moreover, new ideas of the learners in this study were based on reality derived from the interview with the real entrepreneurs and experts. Therefore, it is very likely that the ideas can turn into real products.

To have the learners complete the three components of developing creative entrepreneurship, teachers should arrange teaching and learning for learners to develop new ideas through hand-on experience. This process starts with concrete thought, real implementation based on the ideas created, reflections through exchange and discussion together, and summarizes the knowledge to concrete new ideas next time. Learners have pride and determination to strive for achievement. Learning by doing allow learners to gain significant knowledge and experience enabling them to develop their creativity easily through applying the knowledge and experience. Apart from this, teachers should assign the learners to run a real business. They can sell their products or services as part of activities on campus. This way, they can learn about risk management for investment. In this study, the students were not assigned to run a real business by themselves; therefore, risk taking was not quite developed.

Product development in the third presentation of each group showed increase in creativity when compared with their second presentation. This was because the students had gained knowledge and experience from interview with the enterprises outside classroom. The students were able to develop good ideas for their product development. The learning from real experience can really help developing ideas and adding on ideas or develop creative entrepreneurship of the students because real experiences stimulate the interest of learners. The students will be able to see the possibility of new products that they think and want to continuously develop the product with the instructor as a coach. This goes along with many studies stating that EBL supports developing creativity and/or entrepreneurship (Bridgstock \& Carr, 2013 ; Caniglia et al., 2016 ; Küttim, Arvola \& Venesaar, 2011 ; Parry \& Baird, 2012 ; Yu, 2015). In this study, the students were involved in the interview with the real entrepreneurs. They remembered what is relevant to their products, made analysis and interpret from their experience through reflecting, assessing and reconstructing process to conceptualize their own knowledge from their experience for their product development (Kurka, 2012 ; Lundgren et al., 2017 ; Tsai et al., 2018 ; Kolb, 1984 ; Pittaway and Cope 2007 ; Read et al., 2011; Sarasvathy, 2008). By participating in activities outside classroom, not only can learners gain up-to-date knowledge and real experience, but they can also establish a network which is crucial for becoming an entrepreneur in the future (Williams et al., 2014).

All in all, teachers and/or curriculum administrators should provide activities for learners to have opportunity to learn from real experience or real experts in that particular subject by considering possibility and resources both in terms of budget and personnel to create this type of learning experience for learners. For example, in this study the course was about doing a business in Thailand. In spite of the fact that the 
class was in China, the teacher assigned the students to interview real entrepreneurs in China who are having a business selling the product that they were interested in developing in order to seek advice if the product would be marketed in Thailand. The students had a chance to learn from the perspectives of the real entrepreneurs. Moreover, in their final presentations, the teacher used their connection to invite the experienced experts who specialize in doing business in Thailand to give feedback and suggestions to students for their product development via LINE video calls in order that the expert in Thailand could see the presentations and were able to interact with the students and another expert.

In the next research, the researcher should study and compare EBL in various models which EBL can help develop entrepreneurship the most. EBL in this research is only one model that can develop creative entrepreneurship. The instructor assigns the student to think of a new product, in which the learner gets real experience from both the entrepreneur and business expert. In addition, each activity allows the learner to concrete ideas, implement and reflect on ideas. Throughout the process, there is an instructor who gives advice and a coach.

\section{CONCLUSION AND LIMITATION}

In order to develop creative entrepreneurs, creating real hand-on learning experience is required for learners. This type of learning is called 'Experience-based Learning (EBL)'. In this study, EBL was used to develop creative entrepreneurs of the students who were taking the "Case studies of Business in Thailand" course. The process of learning and teaching began the teacher explained the concept of $6 \mathrm{~W} 1 \mathrm{H}$, PEST and STP. Next, the learners were divided into groups to create a Chinese product or service of their interest to launch a business in Thailand. After that each group presented their products to the teacher and received suggestions on product development. Later, the teacher assigned the learners to interview real entrepreneurs to learn from their experience doing business. The learners then analyzed SWOT and created strategies to run a business operation in Thailand. They were also required to use the CANVAS Model to present the overall picture of their business idea to two experts. This was to allow them to learn from the experts' experience which was beneficial for their product development in the future. This learning process based on EBL enabled the learners to assess themselves. They have increased creative entrepreneurship, particularly perseverance for achievement and innovation and new ideas. Furthermore, the learners also developed more product patterns with creativity and distinctive uniqueness than typical products and services.

Developing new products from Guangxi, China to Thailand, Students do not get the opportunity to sell products or ask questions from Thai customers. Therefore, the students lack of the perspective and real experience from the customers which is an important group for the development of creative entrepreneurs.

\section{REFERENCES}

Baum, J. R. and Bird, B. J. (2010), "The Successful Intelligence of High-Growth Entrepreneurs: Links to New Venture Growth" Organization Science, 21, 2, 397-412. 
Blackburn, J. J., Robinson, J. S., \& Kacal, A. (2015). Determining the Effects of Reflection Type and Cognitive Style on Students' Content Knowledge. Journal of Agricultural Education, 56(3), 195-209.

Bridgstock, R. S., \& Carr, L. (2013). Creative entrepreneurship education for graduate employability in the creative arts. In The CALTN Papers: The Refereed Proceedings of the Creative Arts Learning and Teaching Network Symposium 2013 (pp. 8-35). Tasmanian College of the Arts, University of Tasmania and the Creative Arts Learning and Teaching Network.

Bujor, A., \& Avasilcai, S. (2014). Creative Entrepreneurship in Europe: A framework of analysis. Annals of the Oradea University, Fascicle of Management and Technological Engineering, 23, 151-156.

Bujor, A., \& Avasilcai, S. (2016). The creative entrepreneur: A framework of analysis. Procedia-Social and Behavioral Sciences, 221, 21-28.

Caniglia, G., John, B., Kohler, M., Bellina, L., Wiek, A., Rojas, C., ... \& Lang, D. (2016). An experience-based learning framework: Activities for the initial development of sustainability competencies. International Journal of Sustainability in Higher Education, 17(6), 827-852.

Caves, R. E. (2000). Creative industries: Contracts between art and commerce (No. 20). Harvard University Press.

Chen, M. H., Chang, Y. Y., \& Pan, J. Y. (2018). Typology of creative entrepreneurs and entrepreneurial success. Journal of Enterprising Communities: People and Places in the Global Economy, 12(5), 632-656.

Darling, J., Gabrielson, M. and Seristo, H. (2007). Enhancingcontemporaryentrepreneurship: A focus on managementleadership.European Business Review 19(1):4-22.

De Pinho, L. M. F. (2011). Creative business entrepreneurship: the Portuguese creative business incubators. International Journal of Transitions and Innovation Systems, 1(4), 367-382.

DeJong,J.P.J.andDenHartog,D.N.(2007).Howleadersinfluenceemployees'innovative behaviour. European Journal of Innovation Management10(1):41-64.

Fillis, I., \& Rentschler, R. (2010). The role of creativity in entrepreneurship. Journal of enterprising culture, 18(01), 49-81.

Good, D., Boyas, E., \& Klein, P. (2019, March). Evaluating Experience-Based Learning Activities: Working Through the Morass. In Developments in Business Simulation and Experiential Learning: Proceedings of the Annual ABSEL conference (Vol. 46).

Hartley, J., Potts, J., Flew, T., Cunningham, S., Keane, M., \& Banks, J. (Eds.). (2012). Key concepts in creative industries. Sage. 
Kolb, D. A. (1984). Experiential learning: Experience as the source of learning and development. Upper Saddle River: NJ: Prentice Hall.

Kurka, V. J. (2012). Recognizing culture in experiential education: An analysis and framework for practitioners. Master's Capstone Projects. 20. Retrieved from https://scholarworks.umass.edu/cie_capstones/20

Küttim, M., Arvola, K., \& Venesaar, U. (2011). Development of creative entrepreneurship: opinion of managers from Estonia, Latvia, Finland and Sweden. Business: Theory and Practice, 12(4), 369-378.

Lundgren, H., Bang, A., Justice, S. B., Marsick, V. J., Poell, R. F., Yorks, L., ... \& Sung, S. (2017). Conceptualizing reflection in experience-based workplace learning. Human Resource Development International, 20(4), 305-326.

Mollaei, F., \& Rahnama, H. (2012). Experiential education contributing to language learning. International Journal of Humanities and Social Science, 2(21), 268-279. www.ijhssnet.com/journals/Vol_2_No_21_November_2012/31.pdf

Namaziandost, E., Nasri, M., \& Esfahani, F. R. (2019). Pedagogical efficacy of experience-based learning (EBL) strategies for improving the speaking fluency of upper-intermediate male and female Iranian EFL students. International Journal of Research in English Education (IJREE).

Oke,A.,Munshi,N.andWalumbwa,F.O.(2009).Theinfluenceofleadershiponinnovation processes and activities. Organizational Dynamics38(1):64-72.

Otte, P. P. (2016). Integrating sustainable development in higher education through experience-based learning: Insights from experts in team (EiT) for developing a combined theoretical framework. Journal of Education for Sustainable Development, 10(1), 131-159.

Parry, Z., \& Baird, C. (2012). Removing the walls and textbook from the classroom: A case study of one creative entrepreneurship class of multinational students in South Korea. Journal of Learning Design, 5(2), 25-37.

Pittaway, L. and Cope, J. (2007), "Simulating Entrepreneurial Learning: Integrating Experiential and Collaborative Approaches to Learning" Management Learning, 38, 2, 211-233.

Pratt, A. C. (2008). Creative cities: the cultural industries and the creative class. Geografiska annaler: series B, human geography, 90(2), 107-117.

Read, S., Sarasvathy, S. D., Dew, N., Wiltbank, R. and Ohlsson, A.-V. (2011), Effectual Entrepreneurship, Routledge, London.

Reisman, F., Keiser, L., \& Otti, O. (2016). Development, use and implications of diagnostic creativity assessment app, RDCA-Reisman Diagnostic Creativity Assessment. Creativity Research Journal, 28(2), 177-187. 
Sarasvathy, S. D. (2008), Effectuation: Elements of Entrepreneurial Expertise, Edward Elgar, Cheltenham, UK.

Stein, M. I. (1974).Stimulating Creativity: Vol. 1. IndividualProcedures. New York: Academic Press.

Torrance, E.P. (2008). Thinking Creativity with Words. Form A and B. Bensenville, IL: Scholastic Testing Service. Inc.

Tsai, C. W., Shen, P. D., Chiang, I. C., Chen, W. Y., \& Chen, Y. F. (2018). Exploring the effects of web-mediated socially-shared regulation of learning and experience-based learning on improving students' learning. Interactive Learning Environments, 26(6), 815-826.

UNCTAD. (2008). Creative economy report 2008: The challenge of assessing the creative economy towards informed policy-making. Geneva: United Nations Conference on Trade and Development.

Van Den Broeck, H, Cools, E. and Maenhout, T. (2008). A case study of arteconomy: Building bridges between art and enterprise: Belgian businesses stimulate creativity and innovationthrough art. Journal of Managementand Organization14:573-587.

VandenBos, G. R. (2007). APA dictionary of psychology. American Psychological Association, Washington, D.C.

Williams Middleton, K., Mueller, S., Blenker, P., Neergaard, H., \& Tunstall, R. (2014). Experience-based learning in entrepreneurship education-a comparative study of four programmes in europe. In RENT (Research in Entrepreneurship and Small Business) XXVIII (pp. 1-15).

Yu, W. (2015). Suggestions for Introducing Creative Entrepreneurship Education into China's Design Education (Doctoral dissertation, Carleton University).

Zwick, B. (2008). TK McCraw, Prophet of Innovation: Joseph Schumpeter and Creative Destruction, Harvard University Press, Cambridge, MA (2007) ISBN 978-0-674-025233 719+ xi pp., index, \$35.00. Journal of Economic Behavior \& Organization, 68(1), 325-328.

Rerup, C. (2005). Learning from past experience: Footnotes on mindfulness and habitual entrepreneurship. Scandinavian journal of management, 21(4), 451-472.

Yuste, A. P., Díez, R. H., Cotano, J. B., Fernández, J. A. S., \& de Diego Martínez, R. (2014). An Entrepreneurship-Based Learning (EBL) Experience in Information and Communication Technologies (ICTs).

Lyons, E., \& Zhang, L. (2018). Who does (not) benefit from entrepreneurship programs?. Strategic Management Journal, 39(1), 85-112. 